\title{
European Stroke Organisation (ESO)
}

\section{EUROPEAN STROKE ORGANISATION}

The European Stroke Organisation (ESO) is a Paneuropean society of stroke researchers, national and regional stroke societies and lay people organizations that has been founded in December 2007.

Official journal:

\section{Cerebrovascular Diseases}

\section{President:}

Michael Brainin, Austria

\section{President elect:}

Kennedy Lees, United Kingdom

\section{Past President:}

Didier Leys, France

Vice Presidents:

Angel Chamorro, Spain

Heinrich Mattle, Switzerland

\section{Secretary General:}

Patrik Michel, Switzerland

Treasurer:

Turgut Tatlisumak, Finland

Members at Large:

Natan Bornstein, Israel

Valeria Caso, Italia

Delegate CVD:

Michael Hennerici, Germany

Delegate ESC:

José Ferro, Portugal

Chair of Public Relations Committee:

Geert Vanhooren, Belgium

More information at:

www.eso-stroke.org incorporating European Stroke Initiative (EUSI) and European Stroke Council

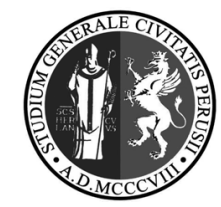

\section{7th ESO Stroke Summer School}

\section{Perugia, Italy, September 8-14, 2013}

The annual ESO Summer School will be held in 2013 in Perugia, Italy from 8th-14th of September. During this weeklong course, stroke specialists from overall Europe will provide their expertise to younger physicians having a major interest in cerebrovascular diseases.

To apply you will have to email the following:

- Application (letter of motivation, CV, letter of support)

- Current affiliation with a European stroke unit

- Maximum 2 participants per country, one per stroke unit

to stroke_unit@med.unipg.it by the deadline of the 28th of February 2013.

Non-European applicants are also encouraged to apply.

The summer school covers all related costs: hotel accommodation, meals, coffee breaks and the social program for participants and speakers. Whereas attendees will have to cover their travel expenses, dinners outside the usual program and any personal expenses during their stay including telephone and internet costs from the hotel. Accompanying persons will not be allowed to attend the events of the program.

More information soon to come on ESO website (www.eso-stroke.org/summer_school2013.php) 